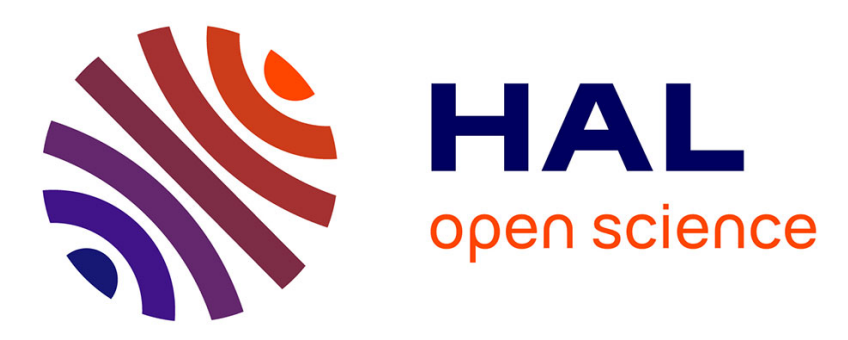

\title{
Foliar Lead Uptake by Lettuce Exposed to Atmospheric Fallouts
}

\author{
Gaelle Uzu, Sophie Sobanska, Geraldine Sarret, Manuel Muñoz, Camille \\ Dumat
}

\section{- To cite this version:}

Gaelle Uzu, Sophie Sobanska, Geraldine Sarret, Manuel Muñoz, Camille Dumat. Foliar Lead Uptake by Lettuce Exposed to Atmospheric Fallouts. Environmental Science and Technology, 2010, 44 (3), pp.1036-1042. 10.1021/es902190u . hal-00559701

\section{HAL Id: hal-00559701 https://hal.science/hal-00559701}

Submitted on 26 Jan 2011

HAL is a multi-disciplinary open access archive for the deposit and dissemination of scientific research documents, whether they are published or not. The documents may come from teaching and research institutions in France or abroad, or from public or private research centers.
L'archive ouverte pluridisciplinaire HAL, est destinée au dépôt et à la diffusion de documents scientifiques de niveau recherche, publiés ou non, émanant des établissements d'enseignement et de recherche français ou étrangers, des laboratoires publics ou privés. 


\section{Foliar lead uptake by lettuce}

\section{exposed to atmospheric fallouts}

Gaëlle Uzu, Sophie Sobanska, Géraldine Sarret, Manuel Munoz and Camille Dumat*

Université de Toulouse ; UPS, INPT ; EcoLab (Laboratoire d'écologie fonctionnelle) ; ENSAT, Av. Agrobiopôle, F-31326 Castanet-Tolosan, France, CNRS ; EcoLab ; F-31326 Castanet-Tolosan, France.

camille.dumat@ensat.fr

\section{RECEIVED DATE}

\section{CORRESPONDING AUTHOR FOOTNOTE}

Corresponding author phone: 0033687294973, fax: 0033562193901 e-mail: camille.dumat@ensat.fr; Sophie Sobanska: LASIR, UMR 8516 USTL, Bâtiment C5 - 59655 Villeneuve d'Ascq cedex, France Géraldine Sarret: Environmental Geochemistry Group, LGIT (UMR 5559), Univ. J. Fourier and CNRS, 38041 Grenoble cedex 9, France; Manuel Muñoz: Mineralogy and Environments group, LGCA (UMR 5025), OSUG - Univ. J. Fourier, 1381 rue de la Piscine, 38041 Grenoble cedex 9, France. 


\section{ABSTRACT}

Metal uptake by plants occurs by soil-root transfer, but also by direct transfer of contaminants from the atmosphere to the shoots. This second pathway may be particularly important in kitchen gardens near industrial plants. The mechanisms of foliar uptake of lead by lettuce (lactuca sativa) exposed to the atmospheric fallouts of a lead-recycling plant were studied. After 43 days of exposure, the leaves thoroughly washed contained $335 \pm 50 \mathrm{mg} \mathrm{Pb} \cdot \mathrm{kg}^{-1} \mathrm{DW}$. Micro X-ray fluorescence ( $\mu$ XRF) mappings evidenced $\mathrm{Pb}$-rich spots of a few hundreds of micrometers in diameter located in necrotic zones. These spots were more abundant at the base of the central nervure. Environmental scanning electron microscopy coupled with energy dispersive X-ray microanalysis (ESEM-EDX) showed that smaller particles (few $\mu \mathrm{m}$ in diameter) were also present in other regions of the leaves, often located beneath the leaf surface. In addition, submicrometric particles were observed inside stomatal openings. Raman Microspectrometry (RMS) analyses of the leaves identified smelter-originated $\mathrm{Pb}$ minerals but also secondary phases likely resulting from the weathering of original particles. Based on these observations, several pathways for foliar lead uptake are discussed. A better understanding of these mechanisms may be of interest for risk assessment of population exposure to atmospheric metal contamination.

BRIEFS. The mechanisms of foliar uptake of lead in lettuce exposed to atmospheric Pb-rich fallouts are studied.

\section{INTRODUCTION}

Particles emitted in the atmosphere present a large variety of sizes (1) and during the last decade, the proportion of fine particle matter (PM) increased with the use of more effective filters in industry (2). $\mathrm{PM}_{10}(\mathrm{PM}$ whose aerodynamic diameter is less than $10 \mu \mathrm{m})$ are target species of the World Health Organization (3) and the European Union Framework Directive on ambient air quality assessment (4) due to their adverse effects on the environment and human health. While $\mathrm{PM}_{2.5}, \mathrm{PM}_{1}$ and nanoparticles 
are minor components of total emitted particles, they are probably the most important in terms of environmental impact. Indeed, they can be transported over long distances in the troposphere (5-6) and due to their high specific area they can strongly impact the biosphere (7-8).

At the global scale, fallouts of atmospheric PM represent the main source of lead pollution in soils (9). Despite the strong decrease in industrial and vehicle lead emissions in recent decades (10), leadenriched PM are still emitted in the environment, especially by lead-recycling facilities (11-12-13). In a previous study on particles rejected by such a facility, a large proportion of submicrometric size particles was observed (7). Toxic for living organisms even at low concentrations (14), lead can be ingested as polluted soil and dust particles by children (15). Additional routes of exposure, which are more important for adults, include drinking water contamination and consumption of locally produced vegetables grown in kitchen gardens (16).

Lead is known to be weakly mobile in soils (17-18), with a residence time estimated to several hundreds of years (19). Lead concentrations in vegetables from kitchen gardens contaminated by atmospheric PM are not correlated with soil contents (20). The main reason is that plant uptake is correlated to the phytoavailable fraction of lead rather than to the total metal burden. However, this absence of correlation may be due to a direct metal contamination through the shoots. Airborne contamination of plants by lead and other metals (21-22-23) and by radionuclides (24) was evidenced in previous studies. However, the mechanisms responsible for the foliar uptake are still unclear and the literature on this topic is very limited compared to soil-root transfer. Most studies on foliar transfer concern plant nutrients in the context of foliar fertilization (25-26-27-28) and to our knowledge there is no study on the mechanisms of foliar uptake of lead.

Terrestrial plants have kept from their aquatic ancestors the ability to absorb nutrients through the leaves (25), and contaminants may follow the same pathway. Nutrients and contaminants have to cross several physical barriers before entering the cytosol of epidermal cells. This penetration is strongly dependant of weather conditions, plant species, physiological status and speciation of the element (26). There are two parallel routes for crossing the cuticle, the lipophilic and the hydrophilic pathway (29-30). 
The lipophilic pathway is not considered in this study because it concerns apolar and non-charged molecules, which cross the cuticle by diffusion in cutin and waxes. Ions and hydrophilic solutes follow the hydrophilic pathway via aqueous pores (29). This pathway requires dissolution of the compounds which depends mostly on the humidity, and on the hygroscopicity and solubility of the particles (26). When the humidity is above the point of deliquescence, the compound partly dissolves and penetration proceeds from this saturated solution. Aqueous pores are located over anticlinal walls and on cuticular ledges of stomata guard cells (30-31). Once a contaminant has crossed the cuticle, it may remain in the apoplasm or be transported inside cells (32). Beside this hydrophilic pathway for solutes, a solid-state pathway also exists. Stomata enable the uptake of suspended nanoparticles and their diffusion in the apoplasm. The stomatal pathway is considered as highly capacitive because of its large size exclusion limit $10 \mathrm{~nm}-1 \mu \mathrm{m}$ and its high transport velocity (33).

The first objective of the present study was to evaluate the transfer of lead from atmospheric contamination in lettuce, a widely cultivated vegetable already used as a model plant in metal transfer studies $(16,34-35)$. Secondly, this work aimed at investigating the mechanisms of lead foliar uptake by monitoring $\mathrm{Pb}$ leaves content over a 43-day exposure time and determining its localization and speciation in the leaves. Such knowledge can be of high interest for risk assessment. Lettuces were first exposed to the fallouts of a plant recycling batteries emitting lead-rich particles $(333,000 \mathrm{mg} \mathrm{Pb} / \mathrm{kg}$ particles) have been previously characterized (7). The total content of lead in the leaves was determined after carefully washing. Micro X-ray fluorescence ( $\mu$ XRF) was used to study the distribution of lead and other elements on centimetric zones of leaves with a lateral resolution of $50 \mu \mathrm{m}$. Environmental scanning electron microscopy coupled with energy dispersive X-ray microanalysis (ESEM-EDX) was used to determine the morphology and elemental composition of lead deposits at a higher resolution, and Raman Microspectrometry (RMS) provided the molecular composition of lead-rich areas. The results obtained were then discussed and possible scenarii for lead foliar uptake were proposed. To our knowledge, this is the first study of foliar transfer of metals on vegetable samples originating from a field study using a combination of physical and chemical techniques. 


\section{EXPERIMENTAL SECTION}

Lettuce exposure to atmospheric lead fallouts. Commercial lettuce seeds, "Batavia blonde dorée" cultivar, were surface sterilized with $0.9 \% \mathrm{CaClO}$ for $15 \mathrm{~min}$ and rinsed with deionised water. Lettuces were first grown hydroponically for 10 days before transfer in pots in a greenhouse for 15 days to get plants of about $15 \mathrm{~g}$ (fresh biomass). After this period, 40 lettuces were placed in pots containing four $\mathrm{kg}$ of uncontaminated calcareous soil (total lead concentration: $25 \pm 2 \mathrm{mg} \cdot \mathrm{kg}^{-1}$ ). Each pot contained one plant. A geotextile membrane was placed on the soil surface to protect it against atmospheric fallouts. Plants were exposed for 43 days in the courtyard of a secondary lead smelter which recycles batteries (7). Every ten days, five replicates were harvested. In addition, five control plants placed in an urban area at $15 \mathrm{~km}$ from the smelter were harvested after 43 days. Lead concentration in the courtyard of the recycling-plant was $1 \mu \mathrm{g} \mathrm{Pb} \cdot \mathrm{m}^{-3}$ air and lead concentration in $\mathrm{PM}$ Emissions was $330000 \mathrm{mg} \mathrm{Pb}_{\mathrm{kg}}{ }^{-1}$. According to the French authorities (36), $328 \mathrm{~kg}$ of Total Suspended Particles (TSP) including $31 \mathrm{~kg}$ of lead were emitted by this facility in 2007 . The particles emitted by this smelter were characterized in a previous study by X-ray diffraction and Raman spectroscopy (7). Lead speciation was, in decreasing order of abundance, $\mathrm{PbS}, \mathrm{PbSO}_{4}, \mathrm{PbSO}_{4} \cdot \mathrm{PbO}, \alpha-\mathrm{PbO}$ and $\mathrm{Pb}^{0}$.

Chemical Analysis of soils and vegetables. After harvesting and removal of the roots, the shoot biomass was measured. Each lettuce was cut in four quarters and one was randomly picked for analyses. The leaves were cut at their base, and each one was washed, first in running tap water for 30 seconds and then in two baths of de-ionized water for one minute, in order to eliminate particles present on the leaf surface but not tightly bound. After draining the leaves with a salad-spin and drying at $50^{\circ} \mathrm{C}$ for 48h, leaf and soil samples were digested, in a 1:1 mixture of $\mathrm{HNO}_{3}$ and $\mathrm{H}_{2} \mathrm{O}_{2}$ at $80{ }^{\circ} \mathrm{C}$ for $4 \mathrm{~h}$ and in hot aqua regia, respectively. After filtration, lead concentration was measured by inductively coupled plasma - atomic emission spectrometry (ICP-AES) with an IRIS Intrepid II XDL. The accuracy of the acidic digestion and analytical procedures was checked using the reference material Virginia tobacco leaves, CTA-VTL-2, ICHTJ. Certified values for lead in Tobacco leaves were given for $22.1 \pm 1.2$ 
mgPb.kg-1 dry weight. Measured values for the three replicates were $22.0 \pm 0.9,22.4 \pm 0.8$ and $21.9 \pm$

$0.8 \mathrm{mgPb} . \mathrm{kg}^{-1}$ dry weight. The leaves of the lettuces after 43 days of exposure were then studied by $\mu \mathrm{XRF}, \mathrm{ESEM}-\mathrm{EDX}$ and RMS.

Micro X-ray fluorescence $(\boldsymbol{\mu X R F )}$. Elemental distributions in various regions of the leaves were determined by $\mu$ XRF. Fresh washed leaves were freeze dried, flattened on the sample holder and placed under vacuum. $\mu$ XRF spectra were collected with an EDAX Eagle III XRF spectrometer, equipped with a Rh anode and a poly-capillary that focuses the X-ray beam down to $30 \mu \mathrm{m}$ full width at half maximum (FWHM). An EDX detector with $140 \mathrm{eV}$ resolution was used to measure the X-ray fluorescence. The spectrometer was operated at 15 or $20 \mathrm{kV}$, and 300 to $450 \mu \mathrm{A}$. Centimetric sized X-ray maps were collected over 256 by 200 pixels with steps of 30 to $50 \mu \mathrm{m}$. The counting time was 600 to $2000 \mathrm{~ms}$ per pixel. Detection limits for such apparatus is around $100 \mathrm{ppm}$ for $\mathrm{Pb}$ and other heavy elements. Deconvolution of $\mu \mathrm{XRF}$ spectra were needed since the S K- and Pb M-lines overlap within the $140 \mathrm{eV}$ resolution of the EDX detector (Fig. 1b). It was performed using the EDAX-integrated software Vision32. Despite the peak overlap, the statistics on $\mathrm{Pb}$ fluorescence signal was better using $\mathrm{Pb} \mathrm{M}-$ line than $\mathrm{Pb}$ L-line at higher voltage $(40 \mathrm{kV})$. Elemental maps were combined as RGB (red-green-blue) 3color maps using Matlab ${ }^{\mathrm{TM}}$. In addition, the XRF spectra for the Pb-rich particles obtained by summing single-pixel spectra in the spot of interest were compared.

Environmental Scanning Electron Microscope (ESEM-EDX). Morphology and elemental distribution were studied using an ESEM (Quanta 200 FEI) equipped with an EDX detector Quantax (Rontec). It was operated at $25 \mathrm{kV}$ in the low vacuum mode. Semi-quantification measurements were obtained with ZAF correction and using real standards. Leaves were air dried and fixed on a carbon substrate before analysis. As for the $\mu \mathrm{XRF}$ analyses, $\mathrm{Pb} \mathrm{M}$ - and $\mathrm{S}$ K-peaks were separated by deconvolution.

Raman microspectrometry (RMS). Molecular identification of particles present on or beneath the leaf surface of lettuce leaves was performed using RMS. Leaf samples collected after 43 days of exposure were fixed on a glass plate and mounted on the microscope stage without further preparation. In most 
cases, particles (or leave areas) were analyzed by both ESEM-EDX and RMS after a careful relocalization, thus electronic and optical images as well as elemental and molecular compositions could be compared. RMS measurements were carried out using a Labram Confocal spectrometer and a Labram HR UV 800 (Jobin Yvon, Horiba Gr, France). The Raman backscattering was excited with $632.8 \mathrm{~nm}$ or $266 \mathrm{~nm}$ excitation wavelength supplied by a He-Ne and a solid MBD 266 system (Coherent - laser group), respectively. The beams were focused on the sample surface through an optical objective (visible Olympus objective, X100, 0.9 NA and UV Mitutoyo objective X80, 0.55 NA) with a lateral resolution (XY) less than $1 \mu \mathrm{m}$ in both cases. The excitation using a UV laser (266 $\mathrm{nm})$ was necessary to probe the surface of leaves since many biologically important molecules such as chlorophyll have an intense fluorescence emission when excited in the visible range (400 $\mathrm{nm}<\lambda<800 \mathrm{~nm}$ ). Fluorescence cross sections are typically several orders of magnitude larger than Raman scattering cross-section and masks any underlying Raman spectra. The Raman spectra were analyzed based on the shifts in Raman peak values, changes in full width at half maximum (FWHM) ratios of Raman bands, and normalized intensity variations. For identification of chemical species, measured Raman spectra (band wave number and relative intensities) with flat base line were compared with spectra in established libraries using Spectral Library Search ID 301 software (Thermo Galactic). The hit quality index (HQI) represents the closeness of the match between the unknown and a particular library entry. Raman spectra libraries used are listed in the supporting information. In addition to these databases, Raman spectra of relevant $\mathrm{Pb}$ compounds including solid-state phases and aqueous solutions were recorded to check for possible differences due to instrumental functions. Further information about identification of $\mathrm{Pb}$ minerals using RMS can be found elsewhere $(12,37)$.

Statistical data treatment. Amount of lead in plant obtained were subjected to analysis of variance (ANOVA) with one factor, using the software Statistica, Edition'98 (StatSoft Inc., Tulsa, OK, USA). Significant differences $(\mathrm{p}<0.05)$ were measured by LSD Fisher test. 


\section{RESULTS AND DISCUSSION}

Foliar lead uptake. $\mathrm{Pb}$ average concentrations in washed leaves after $0,13,23,34$ and 43 days of atmospheric fallouts exposure were $0.22 \pm 0.09,69 \pm 15,139 \pm 40,217 \pm 40,335 \pm 50 \mathrm{mg} \cdot \mathrm{kg}^{-1}$ dry weight (DW), respectively. These values were all significantly different, and lead enrichment as a function of time followed a linear law, without plateau at 43 days of exposure:

$[\mathrm{Pb}]_{\text {leaves }}=6.98 \times($ number of days of exposure $), \mathrm{r}^{2}=0.96, \mathrm{n}=5$.

No significant difference in leaf biomass was noticed between control and exposed plants $(40 \pm 5 \mathrm{~g}$ DW after 43 days), and plants stayed green and healthy despite some necrotic spots (see below). The comparison of the total lead concentrations in leaves between the exposed and control plants after 43 days (335 \pm 50 and $5 \pm 3$ mg. $\mathrm{kg}^{-1}$, DW, respectively) suggests a strong foliar lead uptake by exposed plants. Other lettuces cultivated at 250 and 400 meters from the smelter (not investigated in this study) contained 30 and $15 \mathrm{mg} \cdot \mathrm{kg}^{-1}$, DW, respectively. Thus, lead content strongly varies as a function of the distance to the smelter. A survey of reported metal contents in vegetables in potentially contaminated sites (38) showed a great variability as a function of sampling sites and environmental conditions. According to EU requirements for consumption (4), lead concentration shouldn't exceed $0.3 \mathrm{mg} \mathrm{Pb} . \mathrm{kg}^{-1}$ fresh biomass in leaf-vegetables corresponding to $3.26 \mathrm{mg} \mathrm{Pb} . \mathrm{kg}^{-1} \mathrm{DW}$ in our study (DW reached $10.85 \%$ in exposed lettuces). Thus, this threshold value were reached after 0.5 day of exposure in the plant courtyard. The relatively high lead content measured in control plants could result from soil-root uptake. However, this latter hypothesis is not likely because the control soil was chosen for its relatively high $\mathrm{pH}(8.4)$ and carbonates amount $\left(98{\mathrm{~g} . \mathrm{kg}^{-1}}^{-1}\right)$ to minimize $\mathrm{Pb}$ availability $(17,39)$ and low lead content. Lead present in the control plant more likely results from diffuse $\mathrm{Pb}$ contamination of the urban environment.

After exposure, no variation of lead content in the soil contained in the pots was observed $(<30$ $\left.\mathrm{mgPb} \cdot \mathrm{kg}^{-1}\right)$. However, this is not a proof that $\mathrm{Pb}$ root uptake did not occur. Supposing that $\mathrm{Pb}$ contained in the control plants only originates from the substrate (which likely overestimates the soil-root transfer), the amount of lead taken up by roots would represent only $1.5 \%$ of total $\mathrm{Pb}$ measured in the 
leaves after 43 days of exposure in the plant courtyard. So the soil-root uptake of $\mathrm{Pb}$ can be neglected relative to the foliar uptake. In conclusion, the strong $\mathrm{Pb}$ enrichment in exposed plants is due to a foliar contamination. Considering that vegetables were thoroughly washed, lead was at least strongly bound to the leaf surface or internalized.

\section{Lead distribution in the leaves, spatially-resolved speciation and phyto-toxicity symptoms. The} distribution of lead and other elements was investigated at the leaf-scale by $\mu$ XRF on ten leaves on centimetric zones. Figure 1 shows the analysis of the basal part of a leaf. Four lead-rich zones of a few hundreds of micrometers corresponding to brownish necrotic zones were observed (spot 1 to 4 in Fig. 1c). The $\mu \mathrm{XRF}$ spectra for the four spots, obtained by summing single pixel spectra, are shown in Figure $1 \mathrm{~b}$. The spots contain the same elements but in varying proportions: Spot 1 is richer in $\mathrm{S}, \mathrm{Ca}, \mathrm{Si}$ and Fe whereas spots 2, 3 and 4 are richer in Mn, and spot 4 contains less $\mathrm{K}$. The same type of elemental distributions and grain compositions were observed in other parts of the leaves (figure S1, supporting information). A $\mu \mathrm{XRF}$ map of a Pb-rich necrosis obtained at a higher resolution (20 $\mu \mathrm{m}$ step size) showed that although $\mathrm{Ca}$ and $\mathrm{Mn}$ present high local concentrations, their distribution does not quite match $\mathrm{Pb}$ distribution (fig. S2, SI). No diffuse lead concentration was detected in the leaf tissue. The detection limit of the instrument is relatively high (around $100 \mathrm{ppm}$ for $\mathrm{Pb}$ ), so one cannot conclude on the absence of lead in the leaf tissue. Another type of necrosis was observed on the leaves of both on control and exposed plants, small black spots rich in Mn (Fig. 1d). They are symptoms of Mn toxicity resulting from reductive dissolution due to water saturation phenomenon of the substrate (40), and are not related to $\mathrm{Pb}$ contamination. 

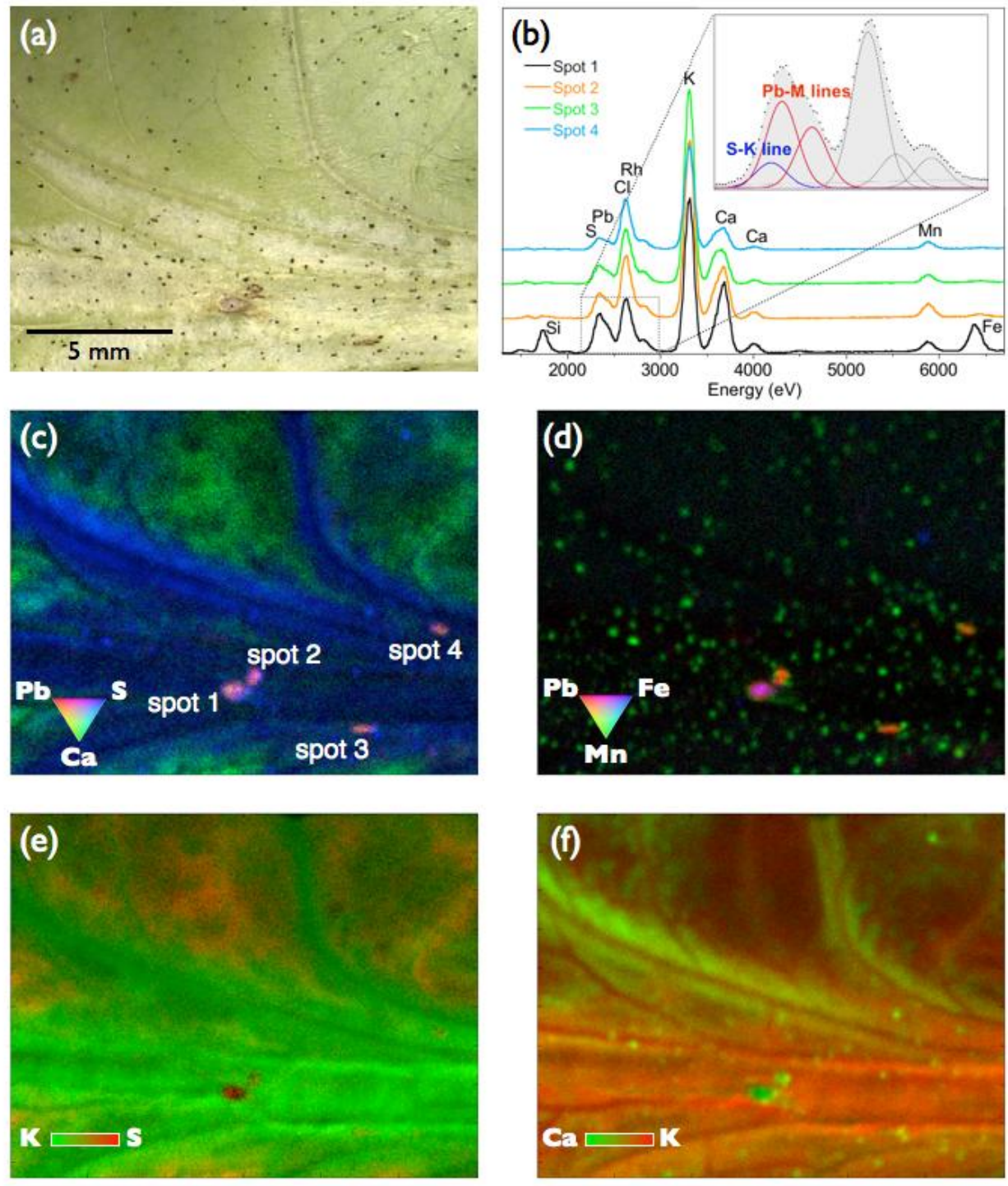

Figure 1. (a) Optical image of the basal part of the lettuce leaf exposed to atmospheric fallouts. Brownish spots correspond to Pb-associated necroses. (b) XRF spectra of Pb-rich necroses shown in (c). (c-f) Tri color and two color $\mu$ XRF elemental maps for $\mathrm{Ca}, \mathrm{Pb}$ and $\mathrm{S}$ (c), $\mathrm{Fe}, \mathrm{Pb}$ and $\mathrm{Mn}(\mathrm{d})$, $K$ and $S(e)$, and $C a$ and $K(f)$. 
The leaves were then studied at a higher resolution by ESEM-EDX and RMS. A variety of Pb-rich necroses were investiagted (Erreur ! Source du renvoi introuvable.a-c and Figure S3, SI). As shown by $\mu \mathrm{XRF}$, EDX maps showed a heterogeneous distribution of $\mathrm{Pb}$ within a $\mathrm{Ca}$ - and $\mathrm{Mn}$-containing phase (Erreur ! Source du renvoi introuvable.b). $\mathrm{P}$ and $\mathrm{K}$ elements were detected in all the necroses, suggesting the presence of an organic membrane covering the precipitates. This organic layer was clearly visible on the secondary electron images (e.g., Erreur ! Source du renvoi introuvable.b-c and Figure S3, SI) and on optical image performed under UV light (e.g., Figure S4, SI). The RMS measurements carried out using a laser beam with a wavelength in the visible region showed an intense fluorescence signal typical of organic substances (e.g. chlorophyll). Measurements using a laser beam at $266 \mathrm{~nm}$ allowed probing the compounds beneath this organic membrane. The $\mathrm{Ca}$, Mn phase was identified by Raman as a mixed carbonate i.e $\left(\mathrm{Ca}_{1-\mathrm{x}} \mathrm{Mn}_{\mathrm{x}}\right) \mathrm{CO}_{3}$ thanks to a characteristic intense Raman band at $1087 \mathrm{~cm}^{-1}$ corresponding to the symmetric stretching $\left(v_{1}\right)$ of carbonate group (symmetry $\left.\mathrm{D}_{3 \mathrm{~h}}\right)$ in the calcite-like structure (space group $R \overline{3} c$ ). Small particles of $\mathrm{MnO}_{2}$ and $\mathrm{PbSO}_{4}$ were found within this carbonate precipitate (Erreur ! Source du renvoi introuvable., SI). The Raman bands at $\sim 1580 \mathrm{~cm}^{-1}$ and $\sim 1300 \mathrm{~cm}^{-1}$ found on many spectra were assignated to carbonaceous material resulting from the degradation of the organic membrane by the laser beam.

Necroses associated to metal accumulations have already been observed for Cd in Brassica juncea $\mathrm{L}$. (41) and Thlaspi caerulescens (42) in the case of metal root uptake, and for $\mathrm{Pb}$ in Arabidopsis thaliana in the case of foliar uptake (43). Necroses are formed by dead cells and are symptoms of relatively acute toxicity. In the present study, metal-rich necroses suggest a toxic effect of metals $(\mathrm{Pb}, \mathrm{Zn}, \mathrm{Fe}, \mathrm{Cu}, \mathrm{Mn}$ depending on the spot, $\mathrm{Pb}$ being generally the most concentrated one). A likely scenario is the transfer of some metals in the intracellular compartment, leading to interferences with the cell metabolism. Further microscopic investigations are required to confirm this hypothesis. 

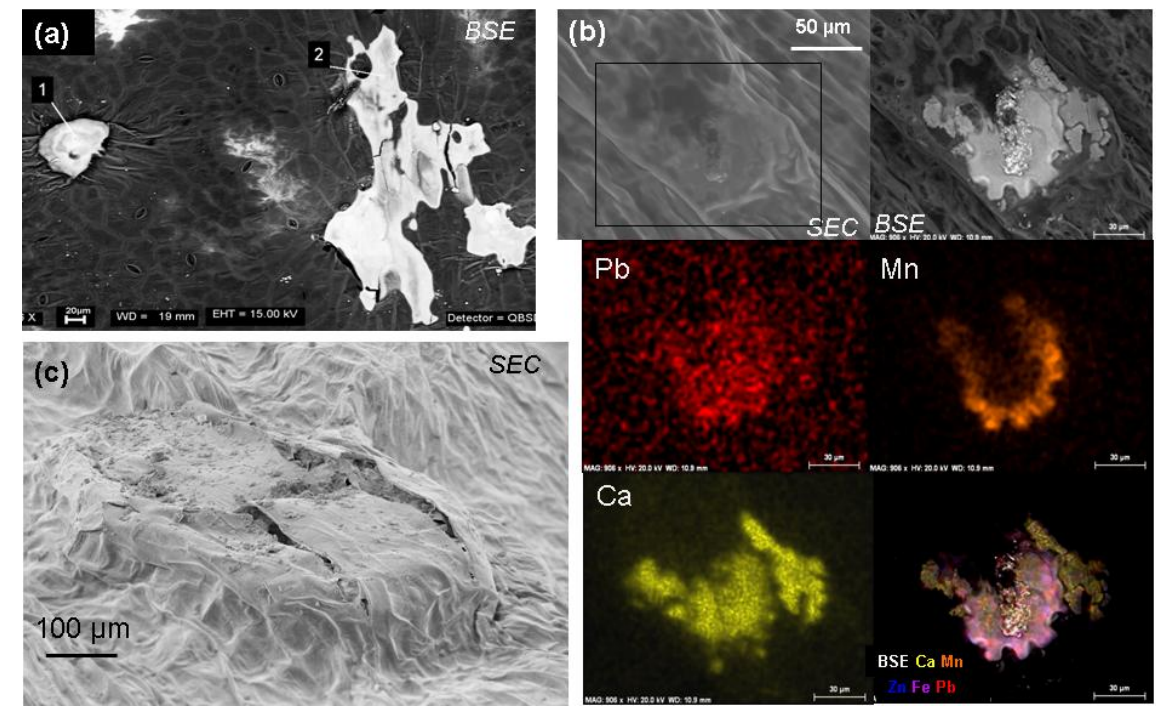
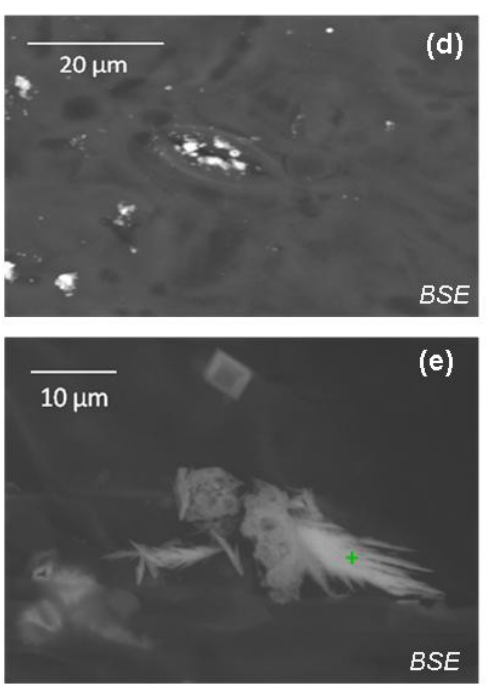

Figure 2 . ESEM-EDX analyses of Pb-rich regions on lettuce leaves exposed to atmospheric fallouts. (a) Two large necroses shown in BSE mode. The EDX semi-quantification for spots 1 and 2 gave $9 \% \mathrm{~Pb}, 1 \% \mathrm{Cl}, 1 \% \mathrm{Mn}, 1 \% \mathrm{Fe}, 20 \% \mathrm{O}, 2 \% \mathrm{Mg}$ and $65 \% \mathrm{P}$. (b) SE and BSE images of a necrosis, elemental distribution of $\mathrm{Pb}, \mathrm{Ca}$ and $\mathrm{Mn}$, and multi-color map showing the distribution of Ca, Mn, Zn, Fe and Mn. (c) SE image of a necrosis. Particles are visible on the leaf surface, as well as beneath the surface. (d) Stomata plugged by Pb-containing particles (e) Secondary Pbcontaining compounds formed on the leaf surface.

In all leaves studied, the base of the central vein contained more particles than the other regions of the leaf. This phenomenon is likely due to rainfall and watering which flushed the particles towards the basal part of the leaves. It was already reported in the case of radionuclide-containing particles (44). In order to reduce the risk induced by vegetables potentially exposed to atmospheric fallouts, a simple recommendation could consist in eliminating the basal part of leaves before consumption.

Particles were also present on the leaf surface (Figure S6, SI). Individual particles and aggregates were a few micrometers to a few tens of micrometers in diameter. The major elements detected by EDX in particles/aggregates were $\mathrm{Pb}, \mathrm{S}, \mathrm{Cl}, \mathrm{Fe}, \mathrm{Ca}, \mathrm{Si}$ and $\mathrm{Al}$. The RMS analysis of the particles allowed the identification of anglesite $\left(\mathrm{PbSO}_{4}\right)$, lanarkite $\left(\mathrm{xPbO} \cdot \mathrm{PbSO}_{4}\right)$, quartz $\left(\alpha-\mathrm{SiO}_{2}\right)$, amorphous iron 
oxyhydroxyde $(\mathrm{FeOOH})$, calcite $\left(\mathrm{CaCO}_{3}\right)$, hydrocerussite $\left(\mathrm{Pb}_{3}\left(\mathrm{CO}_{3}\right)_{2}(\mathrm{OH})_{2}\right)$, cerussite $\left(\mathrm{PbCO}_{3}\right)$ and some fluorescent species attributed to clay minerals (Figure S7, SI). Clay may result from the deposition of non-contaminated dust. $\mathrm{PbS}$ was not detected because this mineral is almost silent in Raman (a weak and broad Raman band is observed at $451 \mathrm{~cm}^{-1}$ ), and this compound readily transform into lead sulphate products under the laser beam (45).

PM were also frequently observed inside stomatal openings on adaxial and abaxial surfaces (Erreur ! Source du renvoi introuvable.d and Fig. S8, SI). These PM had a diameter comprised between $50 \mathrm{~nm}$ and $1 \mu \mathrm{m}$ and minerals identified by RMS included $\mathrm{PbSO}_{4}$ and $\mathrm{PbO}$. The presence of these particles in stomata may have two consequences. Firstly, clogging ostioles disturbs leaf physiology by decreasing the stomatal conductance and gas exchanges and perturbing the water regime, transpiration and control of leaf temperature (46). Secondly, toxic metals may penetrate inside leaves via stomata (33).

Although some aggregates presented the same morphology as source particles characterized previously (7), 3-4\% of needles crystallites were observed on leaf surface (ratio of needle-like particles to the total number of particles observed, Erreur ! Source du renvoi introuvable.e and Fig. S9, SI). These crystallites were not observed in source particles (7). EDX analyses showed $\mathrm{Pb}, \mathrm{K}$ and $\mathrm{Cl}$ as major constituents of the needle structures whereas other elements such as $\mathrm{Sn}, \mathrm{Ca}, \mathrm{K}$ and Fe were found in non-spherical particles associated with the needles. These crystallites were not made of lead phosphate. RMS measurements showed that they were very beam sensitive and intense $\mathrm{PbO}$ and elemental carbon signals were observed after beam damage. These observations suggest that the needles are made of lead-organic species. This was confirmed by spectra recorded at very low laser power on which not very intense Raman bands at $\sim 2800 \mathrm{~cm}^{-1}$ and $\sim 1780 \mathrm{~cm}^{-1}$ characteristic of C-H and C-O bonds, respectively, were observed. These particles may correspond to secondary phases resulting from the dissolution of original particles on the leaf and precipitation with organic compounds present on the cuticle. These changes in particles' morphology and speciation may result from abiotic processes. However, the surface of plant leaves is generally colonized by microorganisms which may participate to 
chemical processes taking place at this interface (47-48). Further investigations are required to evaluate the bacterial colonization on the lettuce leaves and the possible participation of microorganisms to the alteration of the particles.

\section{Potential mechanisms involved in foliar uptake}

The results of this study clearly show that some lead is trapped both on the leaf surface and inside the leaf. Based on our observations and on the present knowledge on foliar uptake of elements, several mechanisms can be tentatively proposed for these processes (Figure 3). Firstly, particles deposited on the leaf surface may be trapped in the tiny folds of the leaf and remain as such. The original particles contain $\mathrm{PbS}$ which is highly reactive and subjected to oxidation and weathering processes, and secondary $\mathrm{Pb}$-containing compounds may form on the leaf surface. The chemical processes of $\mathrm{PbS}$ oxidation under atmospheric conditions have been described previously $(45,49)$, and lead to the formation of $\mathrm{PbO}, \mathrm{PbSO}_{4}, \mathrm{PbO} \cdot \mathrm{PbSO}_{4}$ and $\mathrm{PbCO}_{3}$. These transformations may occur in the atmosphere during the transport of particles, and after their deposition on plant leaves. In parallel, lead may penetrate inside the leaf by two pathways. Firstly, lead-containing nanoparticles observed in the stomata may penetrate in the apoplasm as solid compounds. In this study nanoparticles were observed only in stomatal openings. Further analyses, particularly the study of leaf cross sections, are necessary to test whether nanoparticles enter the leaves via stomata. In addition, particles were observed beneath an organic membrane, probably the cuticle. Again, further investigations are needed to determine their exact localization and the way they were transferred in this place. Secondly, lead resulting from the dissolution of source particles may diffuse through aqueous pores of the cuticle and of the stomata, following the hydrophilic pathway inducing the formation of necroses enriched with lead. 


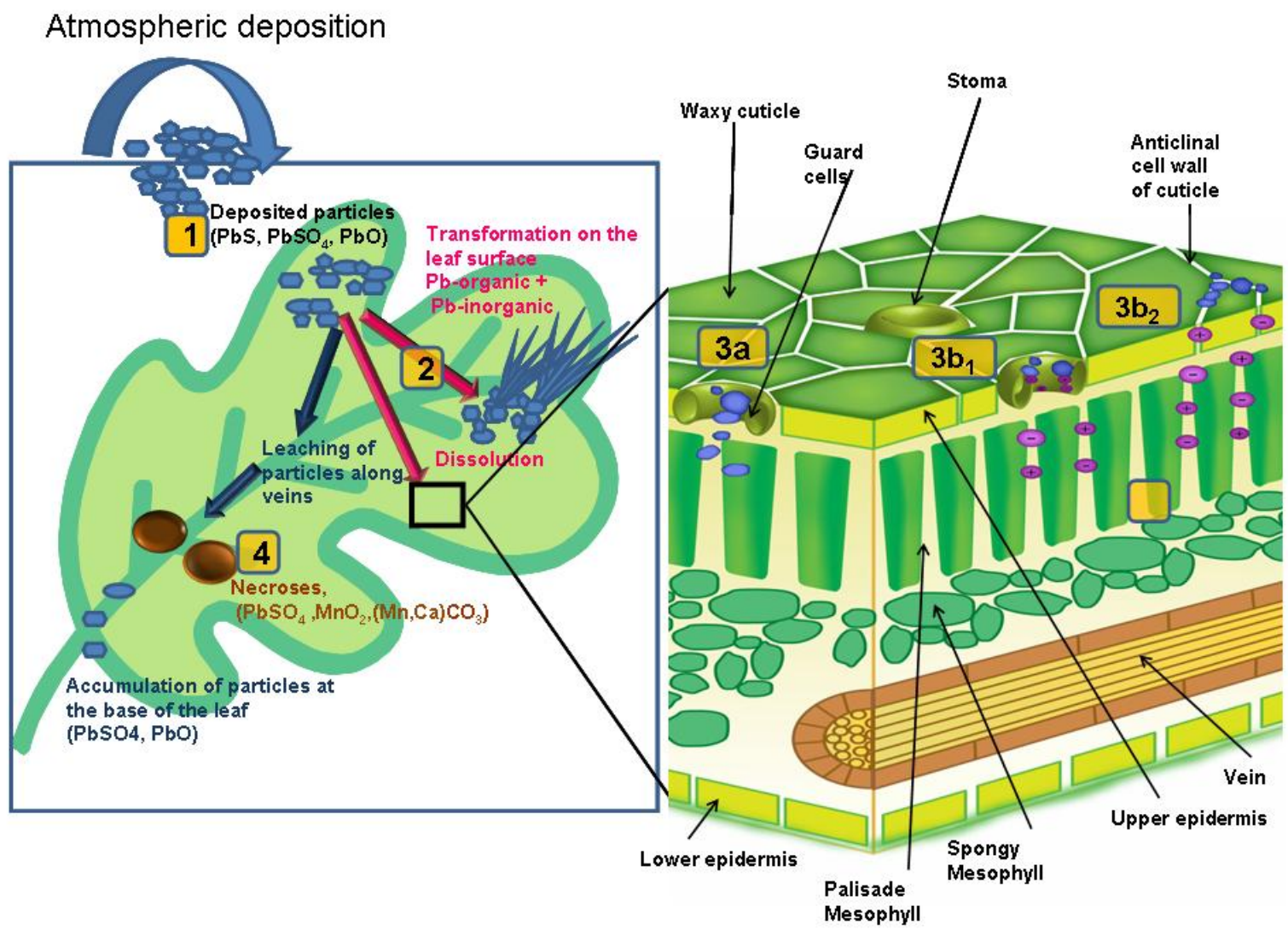

Figure 3. Tentative pathways for lead uptake after deposition of Pb-containing particles. Deposition of particles on the leaf surface (1), chemical transformation on the leaf surface leading to secondary Pb-containing phases and possibly solutes (2). Accumulation of particles in stomata and possibly penetration of nanoparticles (3a). Possible diffusion of solutes via aqueous pores present on cuticular ledges of stomata $\left(3 b_{1}\right)$ and anticlinal cell walls of cuticles $\left(3 b_{2}\right)$. Toxicity symptoms (necroses) induced by the presence of the contaminated particles on the leaf (4).

Our results suggest that various pathways may lead to foliar uptake of $\mathrm{Pb}$ by lettuce exposed to $\mathrm{Pb}$ rich PM. The fate of metal contaminants in the soil and their soil-plant transfer has to be evaluated in metal-contaminated soils, but the foliar transfer is another important issue, which is much less studied. Indeed, in the context of agricultural activities established near metallurgic activities, plant metal uptake may occur predominantly via foliar contamination by micro- and nanoparticles. Microscopic and microspectroscopic investigations of the plants provided insights on the fate of PM deposited on lettuce 
leaves. Such knowledge may be of interest on a physiological point of view and in the perspective of risk assessment of atmospheric emissions in urban environments.

\section{ACKNOWLEDGMENTS}

ADEME, the French Agency for Environment and Energy as well as the STCM, are acknowledged for their financial support and technical help. This research project was supported by the National CNRS CYTRIX-EC2CO program. We thank M. Boidot for Figure 3, P. Recourt from Laboratoire Geosystèmes, UMR CNRS 8157, University of Lille for ESEM-EDX measurements, and M. Corazzi for his help during the $\mu \mathrm{XRF}$ measurements.

\section{REFERENCES}

1. Zhang, Z. ; Kleinstreuer, C. ; Donohue, J. ; Kim, C. Comparison of micro- and nano-size particle depositions in a human upper airway model. Journal of Aerosol Science. 2005, 36, 211-233.

2. Müller, D.; Mattis, I.; Kolgotin, A.; Ansmann, A.; Wandinger, U.; Althausen, D. Characterization of atmospheric aerosols with multiwavelength Raman lidar. In Proceedings of SPIE, Florence, Italy. 2007, pp 67500G-67500G-11.

3. WHO. Air Quality Guidelines for Europe. European Series. 1987, number 23.

4. European Commission. 2002. Commission Regulation (EC) No 221/2002 of 6 February 2002 amending Regulation (EC) No 466/2001 setting maximum levels for certain contaminants in foodstuffs.

5. Dordevic, D.; Vukmirovic, Z.; Tosic, I.; Unkasevic, M. Contribution of dust transport and resuspension to particulate matter levels in the Mediterranean atmosphere. Atmospheric Environment. 2004, 38, 3637-3645. 
6. Arimoto, R. Eolian dust and climate: relationships to sources, tropospheric chemistry, transport and deposition. Earth-Science Reviews. 2001, 54, 29-42.

7. Uzu, G.; Sobanska, S.; Aliouane, Y.; Pradere, P.; Dumat, C. Study of lead phytoavailability for atmospheric industrial micronic and sub-micronic particles in relation with lead speciation. Environmental Pollution. 2009, 157, 1178-1185.

8. Fernandez Espinosa, A. J.; Oliva, S. R. The composition and relationships between trace element levels in inhalable atmospheric particles (PM10) and in leaves of Nerium oleander L. and Lantana camara L. Chemosphere. 2006, 62, 1665-1672.

9. Donisa, C.; Mocanu, R.; Steinnes, E.; Vasu, A. Heavy Metal Pollution by Atmospheric Transport in Natural Soils from the Northern Part of Eastern Carpathians. Water, Air \& Soil Pollution. 2000, 120, $347-358$.

10. Glorennec, P.; Bemrah, N.; Tard, A.; Robin, A.; Bot, B. L.; Bard, D. Probabilistic modeling of young children's overall lead exposure in France: Integrated approach for various exposure media. Environment International. 2007, 33, 937-945.

11. Sobanska, S.; Ledesert, B.; Deneele, D.; Laboudigue, A. Alteration in soils of slag particles resulting from lead smelting. Comptes Rendus de l'Academie des Sciences - Series IIA - Earth and Planetary Science. 2000, 331, 271-278.

12. Batonneau, Y.; Bremard, C. ; Gengembre, L. ; Laureyns, J. ; Le Maguer, A. ; Le Maguer, D. ; Perdrix, E. ; Sobanska, S. Speciation of PM10 Sources of Airborne Nonferrous Metals within the 3-km Zone of Lead/Zinc Smelters. Environmental Science \& Technology. 2004, 38, 5281-5289.

13. Ohmsen, G. S. Characterization of fugitive material within a primary lead smelter. J. Air Waste Manag. Assoc. 2001, 51, 1443-1451. 
14. Canfield, R. L.; Henderson, C. R.; Cory-Slechta, D. A.; Cox, C.; Jusko, T. A.; Lanphear, B. P. Intellectual Impairment in Children with Blood Lead Concentrations below $10 \mu \mathrm{g}$ per Deciliter. N. Engl. J. Med. 2003, 348, 1517-1526.

15. Alloway, B. J. Heavy metals in soils. $2^{\text {nd }}$ Edition, Blackie Academic \& Professional, London. 1995.

16. Alexander, P.; Alloway, B.; Dourado, A. Genotypic variations in the accumulation of $\mathrm{Cd}, \mathrm{Cu}, \mathrm{Pb}$ and Zn exhibited by six commonly grown vegetables. Environmental Pollution. 2006, 144, 736-745.

17. Cecchi, M.; Dumat, C.; Alric, A.; Felix-Faure, B.; Pradere, P.; Guiresse, M. Multi-metal contamination of a calcic cambisol by fallout from a lead-recycling plant. Geoderma. 2008, 144, 287298.

18. Dumat, C.; Chiquet, A.; Gooddy, D.; Aubry, E.; Morin, G.; Juillot, F.; Benedetti, M. F. Metal ion geochemistry in smelter impacted soils and soil solutions. Bulletin de la Société Géologique de France. 2001, 172, 539-548.

19. Klaminder, J.; Bindler, R.; Laudon, H.; Bishop, K.; Emteryd, O.; Renberg, I. Flux rates of atmospheric lead pollution within soils of a small catchment in northern Sweden and their implications for future stream water quality. Environmental Science \& Technology. 2006, 40, 4639-4645.

20. Douay, F.; Roussel, H.; Pruvot, C.; Loriette, A.; Fourrier, H. Assessment of a remediation technique using the replacement of contaminated soils in kitchen gardens nearby a former lead smelter in Northern France. Science of The Total Environment. 2008, 401, 29-38.

21. Tjell, J.C.; Hovmand, M.F.; Mosbaek, H. Atmospheric lead pollution of grass grown in a background area in Denmark. Nature. 1979, 280, 425-426.

22. Mosbaek, H.; Tjell, J.C.; Hovmand, M.F. Atmospheric lead input to agricultural crops in Denmark. Chemosphere. 1989, 19, 1787-1799. 
23. Kozlov M.V.; Haukioja E.; Bakhtiarov A.V.; Stroganov D.N.; Zimina S.N. Root versus canopy uptake of heavy metals by birch in an industrially polluted area: contrasting behavior of nickel and copper. Environmental Pollution. 2000, 107, 413-420.

24. Madoz-Escande, C.; Henner, P.; Bonhomme, T. Foliar contamination of Phaseolus vulgaris with aerosols of $137 \mathrm{Cs}, 85 \mathrm{Sr}, 133 \mathrm{Ba}$ and $123 \mathrm{mTe}$ : influence of plant development stage upon contamination and rain. Journal of Environmental Radioactivity. 2004, 73, 49-71.

25. Mengel, K. Alternative or complementary role of foliar supply in mineral nutrition. In Proceedings of the international symposium on foliar nutrition of perennial fruit plants (Tagliavini, M., Toselli, M., Bertschinger, L., Neilsen, D. and Thalheimer, M., Éd.), International Society Horticultural Sc., po box 500, 3001 Leuven 1, Belgium., PO BOX 500, 3001 LEUVEN 1, BELGIUM. 2002, pp 33-47.

26. Schönherr, J.; Luber, M. Cuticular penetration of potassium salts: Effects of humidity, anions, and temperature. Plant and Soil. 2001, 236, 117-122.

27. Ferrandon, M.; Chamel, A. Foliar uptake and translocation of iron, zinc and manganese - influence of chelating-agents. Plant physiology and biochemistry. 1989, 27, 713-722.

28. Chamel, A.; Bougie, B. Foliar uptake of copper - studies on cuticular sorption and penetration, Vegetal Physiology. 1977, 15, 679-693.

29. Schönherr, J. Calcium chloride penetrates plant cuticles via aqueous pores. Planta. 2000, 212, 112-118.

30. Schonherr, J. Characterization of aqueous pores in plant cuticles and permeation of ionic solutes. J. Exp. Bot. 2006, 57, 2471-2491.

31. Eichert, T.; Burkhardt, J. Quantification of stomatal uptake of ionic solutes using a new model system. J. Exp. Bot. 2001, 52, 771-781. 
32. Chamel, A.; Pineri, M.; Escoubes, M. Quantitative determination of water sorption by plant cuticles. Plant, Cell and Environment. 1991, 14, 87-95.

33. Eichert, T.; Kurtz, A.; Steiner, U.; Goldbach, H. E. Size exclusion limits and lateral heterogeneity of the stomatal foliar uptake pathway for aqueous solutes and water-suspended nanoparticles. Physiologia Plantarum. 2008, 134, 151-160.

34. Waisberg, M.; Black, W. D.; Waisberg, C. M.; Hale, B. The effect of pH, time and dietary source of cadmium on the bioaccessibility and adsorption of cadmium to/from lettuce (Lactuca sativa L. cv. Ostinata). Food and Chemical Toxicology. 2004, 42, 835-842.

35. Khan, S.; Aijun, L.; Zhang, S.; Hu, Q.; Zhu, Y. Accumulation of polycyclic aromatic hydrocarbons and heavy metals in lettuce grown in the soils contaminated with long-term wastewater irrigation. Journal of Hazardous Materials. 2008, 152, 506-515.

36. DRIRE. Direction régionale de l'industrie de la recherche et de l'environnement.http://www.drire.gouv.fr/midi-pyrenees/.

37. Sobanska, S. ; Ricq, N. ; Laboudigue, A. ; Guillermo, R. ; Bremard, C. ; Laureyns, J. ; Merlin, J.C. ; Wignacourt, J.P. Microchemical investigations of dust emitted by a lead smelter. Environ. Sci. Technol. 1999, 33, 1334-1339.

38. BAPPET-Database on ETM in vegetables. ADEME, INERIS, CNAM, INP, ENSAT,ISA.2008. http://www.sites-pollues.developpement-durable.gouv.fr/DocumentsDiagnostics.asp\#BAPPET

39. Birkefeld, A.; Schulin, R.; Nowack, B. In situ transformations of fine lead oxide particles in different soils. Environmental Pollution. 2007, 145, 554-561.

40. Foy, C. D.; Chaney, R. L.; White, M. C. The Physiology of Metal Toxicity in Plants. Annu. Rev. Plant. Physiol. 1978, 29, 511-566. 
41. Salt, D. E.; Prince, R. C.; Pickering, I. J.; Raskin, I. Mechanisms of Cadmium Mobility and Accumulation in Indian Mustard. Plant Physiol. 1995, 109, 1427-1433.

42. Cosio, C.; DeSantis, L.; Frey, B.; Diallo, S.; Keller, C. Distribution of cadmium in leaves of Thlaspi caerulescens. J. Exp. Bot. 2005, 56, 765-775.

43. Lummerzheim, M. S. Comparative microscopic and enzymatic characterization of the leaf necrosis induced in Arabidopsis thaliana by lead nitrate and by Xanthomonas campestris pv. campestris after foliar spray. Plant, Cell and Environment. 1995, 18, 499-509.

44. Madoz-Escande, C.; Santucci, P. Weather-dependent change of cesium, strontium, barium and tellurium contamination deposited as aerosols on various cultures. Journal of Environmental Radioactivity. 2005, 84, 417-439.

45. Batonneau, Y.; Bremard, C.; Laureyns, J. ; Merlin, J. C. Microscopic and imaging Raman scattering study of $\mathrm{PbS}$ and its photo-oxidation products. Journal of Raman Spectroscopy. 2000, 31, 1113-1119.

46. Hirano, T.; Kiyota, M.; Aiga, I. Physical effects of dust on leaf physiology of cucumber and kidney bean plants. Environmental Pollution. 1995, 89, 255-261.

47. Andrews, J. H.; Harris, R. F. The ecology and biogeography of microorganisms on plant surfaces. Annu. Rev. Phytopathol. 2000, 38, 145-180.

48. Lindow, S. E.; Brandl, M. T. Microbiology of the Phyllosphere. Appl. Environ. Microbiol. 2003, 69, 1875-1883.

49. Choel, M.; Deboudt, K.; Flament, P.; Lecornet, G.; Perdrix, E.; Sobanska, S. Fast evolution of tropospheric $\mathrm{Pb}$ - and $\mathrm{Zn}$-rich particles in the vicinity of a lead smelter. Atmospheric Environment. 2006, 40, 4439-4449. 